\title{
International legal sightseeing
}

\author{
Sofia Stolk ${ }^{1, *}$ and Renske $\operatorname{Vos}^{2, * *}$ \\ ${ }^{1}$ T.M.C. Asser Instituut, R.J. Schimmelpennincklaan 20-22, 2517 JN, Den Haag, The Netherlands Email: s.stolk@asser.nl and \\ ${ }^{2}$ Vrije Universiteit Amsterdam, De Boelelaan 1105, 1081 HV Amsterdam, The Netherlands Email: r.n.vos@vu.nl
}

Imagine you are in New York, taking a stroll down $46^{\text {th }}$ Street and suddenly there you see it: the UN Headquarters. It is a building, an icon, the materialization of the organization which name and logo you use repeatedly throughout teaching and research. Here it stands in concrete form: you can touch it, visit it, take a selfie. The UN explicitly facilitates such sightseeing practices on its premises. International law geeks and unsuspecting tourists alike queue up to enter the Visitor Centre, buy a ticket, join a tour, visit the General Assembly hall, and seek out a blue helmet in the gift shop (Figure 1). Children can join the special 'UN Kids Corridor' tour with interactive games, quizzes, and role-playing that 'help young visitors understand the work of the UN and how it relates to their daily lives'. ${ }^{1}$ Visitors get acquainted with a carefully crafted narrative about the work of the UN. They can absorb the story, but also ignore it, misunderstand it, criticize it, or be distracted by the surroundings.

This spectacular yet trivial manifestation of international law and its partly anticipated, partly unpredictable encounter with a plurality of audiences exemplifies what we call international legal sightseeing. ${ }^{2}$ We find these encounters at sites that are particularly designed to gaze at international law, for example, the UN Visitor Centre, or a human rights film festival but also at unexpected places such as a market stall selling Peace Palace cookie jars, or an advert for an international peace movie contest on the window of a bakery. If one takes an approach of wonder and curiosity, ${ }^{3}$ encounters with international law can be found in unusual places, sometimes accidental or with unintended effects. ${ }^{4}$ Through such occurrences, we have become interested in how international law is presented to 'the public', and in turn in what that public shows up for, and how art often is a mediator in that encounter. The question that drives our engagement with these sites and practices of legal sightseeing is: what is international law doing here? There are at least two ways of understanding this question. On the one hand, it opens-up from our amazement at the manifestation of and encounter with international law at a particular

${ }^{\star}$ Editorial Board; Postdoctoral Researcher at T.M.C. Asser Instituut, Den Haag; Research Fellow at the Centre for the Politics of Transnational Law.

** Lecturer and PhD Candidate at Vrije Universiteit Amsterdam; Research Fellow at the Centre for the Politics of Transnational Law.

${ }^{1}$ See United Nations Visitor Centre website, 'Tour', available at visit.un.org/content/tour-1.

${ }^{2}$ See the Legal Sightseeing website, available at www.legalsightseeing.org; S. Stolk and R. Vos, 'International Legal Sightseeing', (2018) 2 Journal of the Oxford Centre for Socio-Legal Studies, available at www.joxcsls.com/2018/12/09/ international-legal-sightseeing.

${ }^{3}$ In line with what Anne Orford has called 'critical intimacy', approaching international law 'with curiosity rather than suspicion'. See A. Orford, 'Epilogue', in L. J. M. Boer and S. Stolk, Backstage Practices of International Law (2019), at 175; A. Orford, 'Critical Intimacy: Jacques Derrida and the Friendship of Politics', (2005) 6 German Law Journal 31.

${ }^{4}$ The risk being that one starts to find international law literally everywhere, as identified by Hohmann and Joyce in their search for international law's objects, J. Hohmann and D. Joyce, International Law's Objects (2018), 3-4.

\footnotetext{
( The Author(s) 2019. This is an Open Access article, distributed under the terms of the Creative Commons Attribution licence (http:// creativecommons.org/licenses/by/4.0/), which permits unrestricted re-use, distribution, and reproduction in any medium, provided the original work is properly cited.
} 
Figure 1. UN gift shop in New York. Photo: Nina Krijnen.

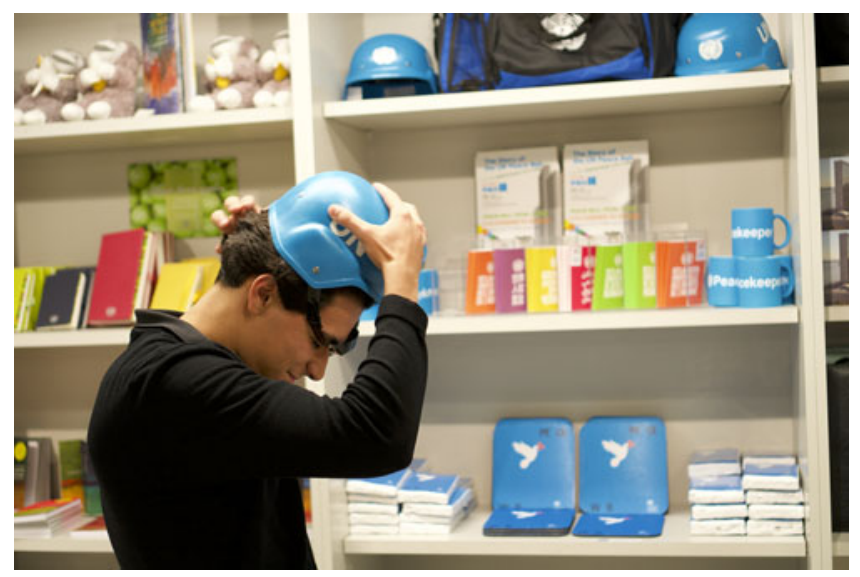

instance: what is it doing here?! On the other hand, we wonder what it does to bring international law to this encounter: what is it doing? For the purpose of this editorial we want to invite the reader along to three stops of legal sightseeing to experience how these two versions of the question arise and to give some tentative answers. At this point, we will not engage with a thorough theorization of the production (who creates these sites and why), nor with a socio-legal inquiry into the reception (how is it experienced and by whom) $)^{5}$ but we describe and analyse the place of encounter and ponder upon the question of what it means to study international law through its sights; with a sense of wonder as our main driver.

By taking legal sightseeing seriously as part of the international legal practice, we situate ourselves within the emerging literature on international law's materiality, visuality, and everyday life. ${ }^{6}$ We also reach out to the work on international law's dramatized discourses and the use of commercial and/or artistic tools to justify and enforce its institutional authority. ${ }^{7}$ An interest in legal sightseeing to us means an interest in the mundane as well as the spectacular side of international law. By inviting tourists to peek behind the scenes, the spectacular of international law has become part of the everyday fabric of the institutional activities. By, for example, turning a running contest into a 'Peace Run', a mundane activity is elevated into the realm of global affairs.

Below, we engage with the multiple faces of legal sightseeing by describing three overlapping and interacting modalities of its encounter: events, sites and objects. The best way of getting a grasp of what we mean by this is for us to showcase and discuss different instances of legal sightseeing. In what follows we do so by stopping at three sites that fascinate us. In line with the rather intuitive character of the legal sightseeing approach, the examples are chosen quite randomly: the Just Peace festival in The Hague; the Nuremberg Palace of Justice; and the

\footnotetext{
${ }^{5}$ In her seminal handbook, Rose identifies four sites of a critical visual methodology: production, the image, its circulation, and its audience. In this piece, we mainly focus on the interplay between image and circulation. G. Rose, Visual Methodologies: An Introduction to Researching with Visual Materials (2016), at 24.

${ }^{6}$ See, for example, Hohmann and Joyce, supra note 4; F. Johns, Non-legality in International Law: Unruly Law (2013); Legal Materiality research network, www.legalmateriality.wordpress.com; L. Eslava and S. Pahuja 'Beyond the (Post) Colonial: TWAIL and The Everyday Life of International Law', (2012) Verfassung und Recht in Übersee/Law and Politics in Africa, Asia and Latin America 195.

${ }^{7}$ For example, W. G. Werner, 'Justice on Screen: A Study on Four Advocacy Documentaries on the ICC', (2016) 29 Leiden Journal of International Law 1043; C. Schwöbel-Patel, 'Spectacle in International Criminal Law: The Fundraising Image of Victimhood', (2016) 4 London Review of International Law 247; I. Tallgren, S. Humphreys and K. Ainley, special issue on International Criminal Justice On/ And Film in (2018) 6 London Review of International Law; I. Tallgren, 'Stardust of Justice? Celebrity in and by International Law', research paper prepared for the Law and Society Association Annual Meeting 2018; R. Knox and C. Schwöbel-Patel, The Aesthetics and Counter-Aesthetics of International Law (forthcoming).
} 
exhibition 'Hybrid Peace' curated by Vasyl Cherepanyn. They are, however, all three indicative of legal sightseeing and its many manifestations. We use these examples to show how legal sightseeing as lens can apply in various ways and how it invokes similar questions in different contexts.

The showcasing of these snapshots signals how widely legal sightseeing occurs. Some examples might spark recognition, whereas others are perhaps more curious. It is true that there is a certain discomfort that shines through in our discussion of the encounter between international law and its public. That discomfort should not be taken to signify our judgment of this encounter, rather it is the point at which we begin to look again. We all are likely to partake, ourselves included, in practices of legal sightseeing. Rather than only trivial, these encounters can be important. We would like to use this Editorial to introduce legal sightseeing as a lens that allows for a creative and intuitive approach to international law, and to pause to reflect on what it means to find ourselves in this encounter.

\section{Just Peace Festival}

The aim of the annual Just Peace Festival in The Hague is 'to give peace \& justice an important place in the hearts and actions of our inhabitants, entrepreneurs and organizations', whom it seeks to attract. ${ }^{8}$ It is attended by around 40,000 visitors annually. ${ }^{9}$ The festival is organized as a collaborative effort between cultural, educational, and international institutions in the week leading up to the International Day of Peace of the United Nations. The programme consists of, e.g., exhibitions, film screenings, debates, walks, concerts, lectures, and a run. ${ }^{10}$ Justice literally becomes a festival. Part of this festival is 'The Hague International Open Day'11 on which international institutions open their doors to visitors or organize extra activities such as tours, Q\&A sessions, meet\&greets, and children's activities such as the OPCW colouring competition (Figure 2).

We consider the Just Peace Festival as exemplar of the eventization of international law, in which justice becomes a spectacle:

As a spectacle, international law is presented both visually and dramatically. This component sits within a wider trend where "justice needs to be seen to be done" to meet an appeal for legitimacy, accountability and transparency. The spectacle of international law is as much a literal seeing of international law as a dramatic invocation of "humanity" as international law's main constituency. International justice becomes sexy, glamorous. ${ }^{12}$

The celebration of international institutions and their ability to bring prosperity to the world is also part of the larger narrative of the city of The Hague, which actively brands itself as the "City of Peace and Justice'. Of course, a festival has - by definition - a festive character. This is emphasized by the many references to the celebration of peace and justice throughout the events. Yet most of these events have a serious undertone as well, even if overall a feeling of empowerment and optimism prevails. This is not unique to the Just Peace festival; a similar tension between the festive

\footnotetext{
${ }^{8}$ Just Peace Platform, available at www.justpeacethehague.com/en.

${ }^{9}$ Ibid., at 'Info' page.

${ }^{10}$ See 'Program' at www.justpeacethehague.com/en/program.

${ }^{11}$ The Hague International Open Day website at internationaledag.nl/en/.

${ }^{12}$ Stolk and Vos, supra note 2. On the appeal for legitimacy, accountability, and transparency see N. Hayashi and C. M. Bailliet (eds.), The Legitimacy of International Criminal Tribunals (2017); A. Bianchi and A. Peters (eds.), Transparency in International Law (2013); J. Dobson, 'Mapping the Transparency Turn at the International Criminal Court', (PhD thesis, VU Amsterdam forthcoming, on file with authors). On the literal seeing of international law see Werner, supra note 7. On international justice as sexy and glamorous see Tallgren, supra note 7; P. Akhavan, 'Making Human Rights Sexy: Authenticity in Glamorous Times', Harvard Human Rights Journal Blog, 29 November 2012, available at harvardhrj.com/2012/11/makinghuman-rights-sexy-authenticity-in-glamorous-times/.
} 
Figure 2. The Hague International Open Day 2017. Photo: Sofia Stolk.

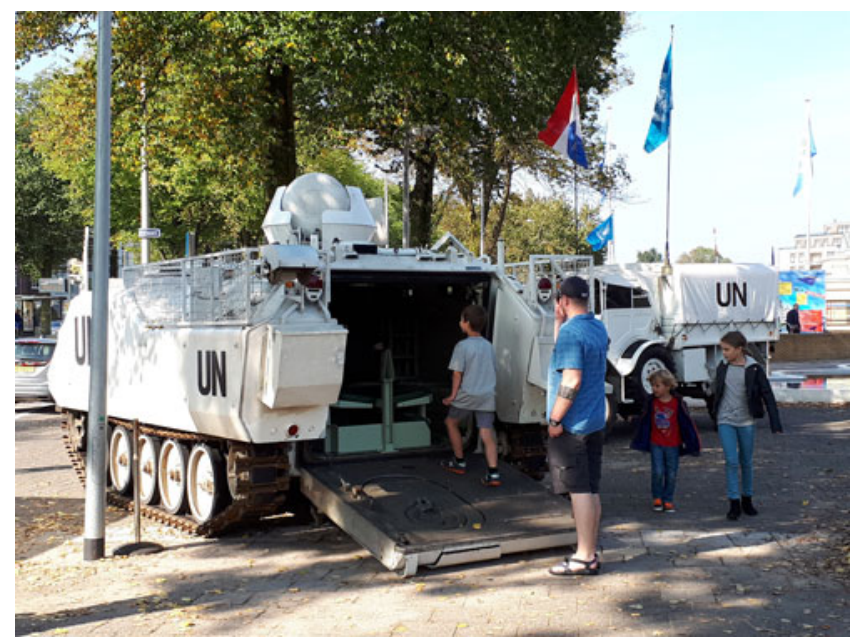

and the serious can occur at a - still growing - variety of human rights film festivals. Where on the one hand it can make for a relaxing evening out to watch a film, the subject matter of these films is often serious and sometimes harrowing. ${ }^{13}$

The Just Peace festival is not part of the everyday of international law, but of the once-a-year. It is an event that recurs annually. The exceptional character of the event is meant to attract the public but what does the public show up for? On this special occasion, visitors can enter a building that they would otherwise not be allowed to access. There is an almost childlike sensationalism and excitement in entering an otherwise forbidden space. Once inside, institutions show their most spectacular sides: not the offices, paperwork, and photocopy machines, but the tanks, photos of victims, stories of how these institutions 'make the world a safer place'. Is it unimaginable that an audience would want to see the files piled up on the corners of desks, the coffee stains in the carpet, the abandoned water cooler? Such trivia make the space real. In a way, the festival assumes that international law, as it is, is not attractive enough by presenting a certain stylized image of what international law is.

Visiting one of the discussion programmes in the Peace Palace during the 2017 festival, led us to reflect on the particular setting and audience. The event treats its audience to a multisensory experience. There is wine at the entrance, the room is dynamically set-up around an oval stage, speakers wear headsets and make no use of paper but perform their speech freely walking around, surrounded by photographers and film crews. All presentations are live-streamed on Facebook. Not only words but also dance, cartoons, images, artworks, documentary film, and music are doing the talking. The speakers are invited because they are, in different ways, 'setting peace and justice in motion'. All contributions start with a personal anecdote, helping the audience to visualize different times and different spaces, to empathize with the story. From a legal sightseeing perspective we were wondering: Who showed up? Who did the event reach? Was it thought-provoking or preaching to the choir? A large part of the audience seemed to consist of students in, for example, international relations, international law, and development studies. Their attendance had both an idealistic and a pragmatic significance. Next to questions about substance, they wanted to know how to get a job in an organization contributing to a more peaceful society. In most questions and contributions, peace and justice were celebrated as the ideal, but some cynicism about the potential for action was also aired. Still, in the end, hope and optimism prevailed, reinforced by the musical performances, promotion of crowdfunding campaigns and

${ }^{13}$ On this phenomenon see, for example, S. Tascón, Human Rights Film Festivals: Activism in Context (2015). 
drinks receptions. Both the setting and the content explicitly appealed to the festive character of the event, adding to the spectacular, idealized dimension of international law. ${ }^{14}$

\section{Courtroom 600}

The second site we stop at as a prime example of legal sightseeing makes for quite a different type of experience: a visit to the exhibition Memorium Nürnberger Prozesse in the Palace of Justice in Nuremberg. Courtroom 600 pauses at a grave historical moment in international law: at the scene of the International Military Tribunal, which followed the end of the Second World War. At the same time, as a tourist sight, it cannot get away from the trivialities of museum reality, such as signposting and the logistics of an (audio)tour. By emphasizing its history, an 'ordinary' active Court turns into a spectacle.

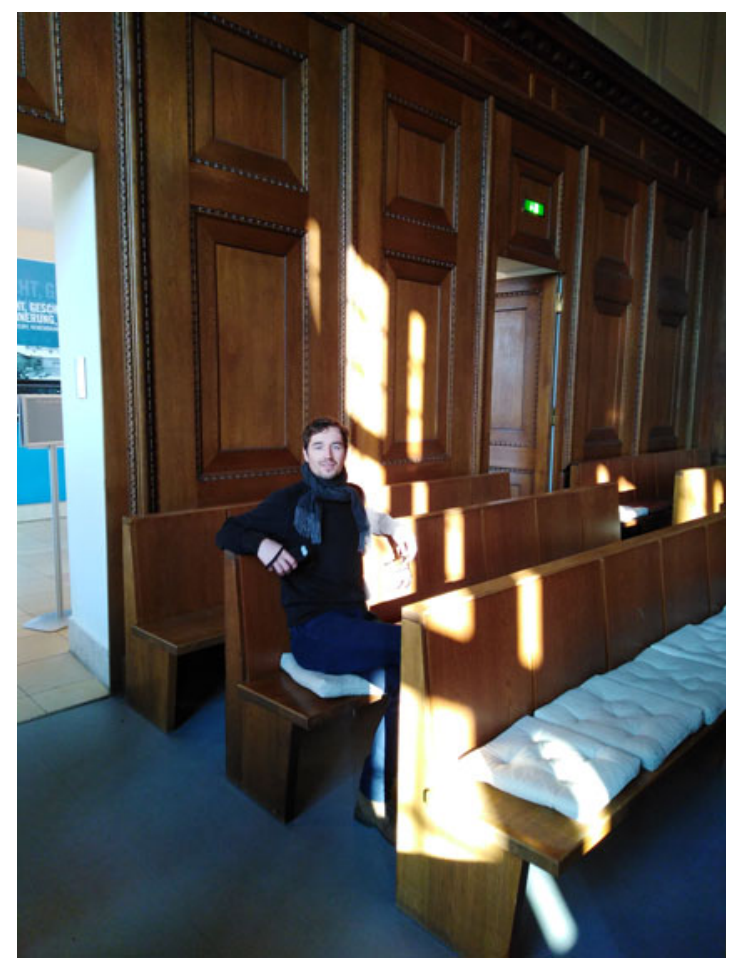

Figure 3. A tour in Courtroom 600. Photo: Valeria Posada Villada and Dion Kramer.

In Figure 3, we see our colleague, audio-guide in hand, museum signposting in the background, looking out of place. We see him facing the camera unsure of whether to smile. He seems not quite yet to have forgotten about the beautiful weather outside, and is still readjusting to the site he has just entered, Courtroom 600. Here he sits caught in between recognition and estrangement at finally seeing this momentous space. On the one hand, he is spending a relaxing weekend break, on the other hand and at the same time, he is imagining all that has passed here.

Looking at this exhibition in Nuremberg as part of legal sightseeing, should not be understood as a negation of the historical importance of the International Military Tribunal or of the seriousness of the subject matter it dealt with. Memorials and museums have a distinct role in guarding

\footnotetext{
${ }^{14}$ Reflections are based on legalsightseeing.org/2017/10/04/hague-talks-setting-peace-and-justice-in-motion/.
} 
and signifying history and memory, ${ }^{15}$ specifically with regard to war and conflict, which is discussed at length in the fields of for example museum studies, ${ }^{16}$ transitional justice and memory law. ${ }^{17}$ It is precisely because of this distinct role, that we are interested in the encounter between this Court as museum/memorial and its visitors. There is such a wide range of literature that discusses different aspects of this phenomenon that our brief glance will necessarily be superficial and undertheorized. But we hope to offer some insight into the many types of questions the legal sightseeing lens can invoke.

The touristification of this particular historical site can be analysed as an instance of 'dark tourism', a term coined by Lennon and Foley. ${ }^{18}$ 'Dark tourism' is a loaded term in a sensitive debate, ${ }^{19}$ but for the purpose of this piece we would like to follow the definition of Tarlow: 'visitations to places where tragedies or historically noteworthy death has occurred and that continue to impact our lives', ${ }^{20}$ which does justice to the diversity of manifestations and connected motivations and experiences. ${ }^{21}$ Other examples of such sites are the Museum of Genocide and Killing Fields in Cambodia, ${ }^{22}$ the Nanjing Massacre Memorial $\mathrm{Hall}^{23}$ and the Apartheid Museum in Johannesburg. ${ }^{24}$ Sites such as the grounds and buildings of the Auschwitz-Birkenau camps have also been labelled as belonging to a sub-category 'Holocaust tourism' ${ }^{25}$

The Nuremberg courtroom signifies, in a way, a slightly more 'light' note in this otherwise dark history and array. Nuremberg has an ambivalent past as both a significant city in Nazi Germany and the place where the Nazi leadership faced trial after the war, the latter being emphasized in the memorial exhibition. ${ }^{26}$ The courthouse, as a memorial, highlights the role of law to speak to power, and of the power of law to bring criminals to justice. As an audience, being in the actual courtroom can almost make you 'feel' this history.

Visiting a place with such a grave history evokes both feelings of interest and estrangement. On the one hand, it turns an abstract but famous place into a real, physical place, yet at the same time it alters or even breaks down the imagination. Posada Villad and Kramer note that '[a]s soon as

\footnotetext{
${ }^{15} \mathrm{~A}$. Witcomb, 'Remembering the dead by affecting the living: the case of a miniature model of Treblinka', in S. Dudley (ed.), Museum Materialities: Objects, Engagements, Interpretations (2010), at 39, 42.

${ }^{16}$ See, for example, J. Winter, 'Museums and the Representation of War', (2012) 10 Museum and Society 150; A. Alba, The Holocaust Memorial Museum: Sacred Secular Space (2015); J. Apsel, Introducing Peace Museums (2015); A. Milosevic 'Remembering The Present: Dealing With The Memories Of Terrorism In Europe', (2017) 8 Journal of Terrorism Research 44.

${ }^{17}$ U. Belavusau and A. Gliszczyńska-Grabias, Memory: Towards Legal Governance of History (2017); J. N. Clark, 'Reconciliation through Remembrance? War Memorials and the Victims of Vukovar', (2013) 7 International Journal of Transitional Justice 116.

${ }^{18}$ J. Lennon and M. Foley, Dark Tourism: the Attraction of Death and Disaster (2000).

${ }^{19}$ See, for example, D. Light, 'Progress In Dark Tourism And Thanatourism Research: An Uneasy Relationship With Heritage Tourism', (2017) 61 Tourism Management 275; G. M. S. Dann and A. V. Seaton (eds.), Slavery, Contested Heritage and Thanatourism (2001); J. C. Henderson 'War as a tourist attraction: the case of Vietnam', (2000) 2 International Journal of Tourism Research 269.

${ }^{20}$ P. E. Tarlow, 'Dark Tourism: The Appealing "Dark Side” of Tourism and More', in M. Novelli (ed.), Niche Tourism Contemporary Issues, Trends and Cases (2005), at 48.

${ }^{21}$ See also P. Stone, 'A Dark Tourism Spectrum: Towards A Typology of Death and Macabre Related Tourist Sites, Attractions And Exhibitions', (2006) 54 Tourism at 146.

${ }^{22} \mathrm{M}$. Elander, 'Images of Victims: The ECCC and the Cambodian Genocide Museum', in D. Manderson (ed.), Law and the Visual: Representations, Technologies, and Critique (2018); R. Hughes, 'Dutiful Tourism: Encountering the Cambodian Genocide', (2008) 49 Asia Pacific Viewpoint 318-30; J. C. Henderson, 'Communism, Heritage and Tourism in East Asia', (2007) 13 International Journal of Heritage Studies 240.

${ }^{23}$ K. Denton, 'Exhibiting the Past: China’s Nanjing Massacre Memorial Museum', (2014) 12 The Asia-Pacific Journal 1.

${ }^{24}$ D. Newbury, “Lest We Forget": Photography And The Presentation Of History At The Apartheid Museum, Gold Reef City, And The Hector Pieterson Museum, Soweto', (2005) 4 Visual Communication 259.

${ }^{25}$ See also the typology of Stone, supra note 21. For a comparative study of the representation of the Holocaust in memorials and museum/memorials country by country see J. Young, Holocaust Memorials and Meaning: The Texture of Memory (1993).

${ }^{26}$ On the complicated history of Nuremberg see S. Macdonald, Difficult Heritage: Negotiating The Nazi Past In Nuremberg And Beyond (2010).
} 
one goes inside Courtroom 600, it is hard to imagine that the Nuremberg Trials took place in the same place'. ${ }^{27}$ The current building speaks to its history in different ways. The courthouse itself has been renovated and reorganized, ${ }^{28}$ but the original atmosphere is preserved through the exhibition of iconic artefacts: the benches of the accused and the original docket, as well as historical photos and videos. The exhibition on the third floor of the Palace allows visitors to 're-experience' being in the audience in $1945 .{ }^{29}$ One experiences the real courtroom and re-experiences the courtroom as it once was at the same time.

Furthering the ambition to re-experience the past yet following a more experimental course, a team of researchers has begun the development of an immersive learning experience using virtual reality (VR) and game design to bring to life archival materials from the Nuremberg Trials'.$^{30}$ The Courtroom 600 project 'seeks to help users have a personal encounter' thus 'reviving holocaust history with virtual reality'. ${ }^{31}$ This project potentially opens-up ways of virtually 'accessing' and engaging with the space of Courtroom 600 from anywhere else. For all the care and awareness of this group of researchers, we can also admit to a sense of unease to find the words 'VR game' in relation to Courtroom 600. There is a gravity to the space that does not evaporate all that easily, as you are there where it happened, but will that persist virtually? And, what will such a project do to the experience and presentation of international law and its history with those who enter its virtual reality?

Adding to this complex interplay of past and present is the fact that Courtroom 600 is still an active court. This means that visitors can only access the place when the court is not in session. This combined coexistence of past and present neatly illustrates the everyday spectacular that characterizes legal sightseeing. International courthouses as tourist destination regularly have this dual function: the ICC and ICJ both accommodate visitors with exhibitions and guided tours, but are also active courts. This example also invites further reflection on the power of buildings as iconic sites. ${ }^{32}$ Former 'legal' sights can be re-appropriated into tourist sites, for example, prisons and embassy buildings have been turned into galleries or hotels. ${ }^{33}$ These places advertise themselves by appealing to their legal histories. The privilege of accessing these otherwise closed-off sites attracts, even if the original occupants have left a long time ago. There are different stakes in this re-appropriation: for example, we can identify a commercial logic, an emotional logic but also a logic of repetition. Manifestations of repetition, reenactment, or recalling are more often used in international law as a way of linking the present to the past and to simultaneously solidify and update certain meanings. ${ }^{34}$ Visitors experience, or rather re-experience, the historical power and spectacle of international law. Visiting, seeing, and touching the place gives both concrete form and shapes the imagery of international law. The meaning of international law is transformed by its re-appropriation, physically, and mentally.

\footnotetext{
${ }^{27}$ V. Posada Villada and D. Kramer, 'Courtroom 600 and Memorium Nürnberger Prozesse', Legal Sightseeing, 15 May 2019 , available at legalsightseeing.org/2019/05/15/legal-sightseeing-nuremberg/.

${ }^{28} \mathrm{~A}$ brief history of Courtroom 600 can be found on the website of the memorial at museums.nuernberg.de/memoriumnuremberg-trials/permanent-exhibition/courtroom-600/.

${ }^{29}$ Posada Villada and Kramer, supra note 27.

${ }^{30}$ International Society for Presence Research, 'Courtroom 600 VR project to create active, experiential learning about Nuremberg Trials', 16 January 2019, available at ispr.info/2019/01/16/courtroom-600-vr-project-to-create-activeexperiential-learning-about-nuremberg-trials/; J. McBride 'Reviving Holocaust History with Virtual Reality', UConn Today, 9 January 2019, available at today.uconn.edu/2019/01/reviving-holocaust-history-virtual-reality/.

${ }^{31}$ Ibid.

${ }^{32}$ M. Bak McKenna, 'Designing for International Law: The Architecture of International Organisations 1922-1952', London Review of International Law (forthcoming).

${ }^{33}$ For example, the former American Embassy in The Hague, www.onzeambassade.nl/ and the Charles Street Jail in Boston, now called the Liberty Hotel.

${ }^{34}$ W. G. Werner, 'Recall it again, Sam. Practices of Repetition in the Security Council', (2017) 86 Nordic Journal of International Law 151.
} 


\section{Hybrid Peace}

Seen from a legal sightseeing perspective, there is a thin line dividing the memorial from the art gallery. In fact, the visiting experience may be similar in part. Through mostly visual means history and politics are presented to the visitor. ${ }^{35}$ Yet, in turning to the gallery we find not an international institution presenting international law but the artist invoking international law in her work. ${ }^{36} \mathrm{At}$ the two previous stops, art and artists were drawn in to mediate the communication from international law to the public. Art and artists are instrumental in, for example, designing a festival, curating a memorial exhibition, or sculpting a memorial site. However, in galleries and art museums the work of artists on display is not commissioned in the same way.

Figure 4. Visitors at Hybrid Peace, Stroom, The Hague. Photo: Renske Vos.

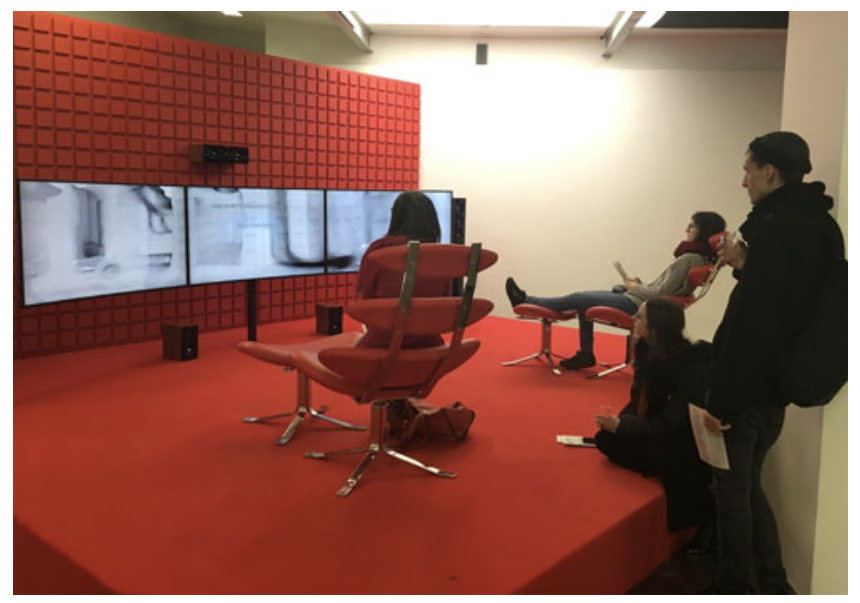

At Stroom, a gallery based in The Hague, Ukrainian artist Vasyl Cherepanyn curated the exhibition 'Hybrid Peace' (Figure 4). ${ }^{37}$ In the exhibition, Cherepanyn evokes allusions to international law to further a political premise. The exhibition in this way seeks to reconsider the hybridity of the boundaries between war and peace in Europe today. Through staging (video)installations, screenings, and discussions, the idea of peace on the continent of a united Europe is revisited. '[W]here there is Europe, there is peace ... Yet the EU finds itself surrounded by a belt of wars at its south and east. ${ }^{38}$ Hybrid warfare has meant that through new technologies war is extended far beyond the battlefield to society, both in and outside of Europe. Conversely, Cherepanyn reconceptualizes this development as hybrid peace, emphasizing how this development affects not only our understanding of war and warfare, but also of peace and safety. He then concludes:

The Hague, City of Peace and Justice, should be at the forefront of recognizing the conditions of hybrid warfare, to imagine its alternative in the field of law, cultural production, and international relations. ${ }^{39}$

\footnotetext{
${ }^{35}$ See, for example, C. Gray, The Politics of Museums (2015).

${ }^{36}$ Unexpected encounters with the international in museums and galleries have been more elaborately studied in the field of international relations; see, for example, C. Sylvester, Art/Museums: International Relations Where We Least Expect It (2015).

${ }^{37}$ Stroom Den Haag, 'Visual Culture Research Center: Hybrid Peace', www.stroom.nl/activiteiten/tentoonstelling.php? t_id=4836243.

${ }^{38}$ V. Cherepanyn, 'Hybrid Peace', Visual Culture Research Center, available at vcrc.org.ua/en/.

${ }^{39}$ Ibid.
} 
Cherepanyn calls on The Hague, City of Peace and Justice, as both the geographical location where the exhibition is held and for what that location stands for as representation of international law and its community. He does not curate this exhibition on behalf of the City of Peace and Justice, he aims to address it. In the space of the gallery he invokes international law and its constituency to frame his political message.

Art gallery Stroom - where Hybrid Peace was exhibited - has a running programme called See You in The Hague, which aims to tell 'a multifaceted narrative about the ambitions and reality of The Hague as International City of Peace and Justice'. In a reflection on this programme, curator Brigitte van der Sande writes:

Artists give us new insights in the contemporary complexities of truth, justice and peace and offer a new language to open up the discussion on the ethics of universal jurisdiction, which for many people in the world is a white man's justice. And they can imagine alternative futures, together with the strategies and tools with which these can be realised. Not fuzzy or vague, but precise, analytical and empathetic. ${ }^{40}$

It is, then, not 'just' international institutions that resort to art for their communication. Artists also communicate with international law by calling attention to international legal issues through art. ${ }^{41}$ In this category, art that stands out is, for example, the presentation of Ai Weiwei's Law of the Journey, a life-size, 60 metre, aluminium and PVC sculpture of refugees crowded on board an inflatable boat, at the 2018 Sydney Biennale. ${ }^{42}$ Also interesting to name in this light, is the work by the research agency Forensic Architecture, which investigates cases of human rights violations and - in addition to presenting investigations in international courtrooms, official inquiries and commissions - exhibits findings in art and cultural institutions. ${ }^{43}$

In the reverse, art is instrumental for courts and tribunals to communicate their message to a wider audience or to present its identity. The ICC frequently hosts exhibitions, a recent example is the photo exhibition 'Justice Matters', ${ }^{44}$ the imagery of the ICJ is inextricably linked to the architecture of the Peace Palace and the works of art that decorate its halls, ${ }^{45}$ and artists have become part of transitional justice initiatives. ${ }^{46}$ These multiple ways of mobilizing art, either in support of international legal practices or as a critical intervention - or both - draw different audiences, with different effects.

\footnotetext{
${ }^{40}$ B. van der Sande, 'See You in The Hague: the Clash of Clans', Stroom Den Haag, 2015, available at www.stroom.nl/ paginas/pagina.php?pa_id=731551.

${ }^{41}$ This opens up an age-old debate on art and its role and responsibilities in society that we cannot do justice to in this short piece. See, for example, C. Becker, The Subversive Imagination: The Artist, Society and Social Responsibility (1994).

${ }^{42} \mathrm{Ai}$ Weiwei, Law of the Journey, Installation view of the $21^{\text {st }}$ Biennale of Sydney (2018), available at www. biennaleofsydney.art/artists/ai-weiwei/; see also, e.g., Ai Weiwei, Safe Passage, exhibition at FOAM Amsterdam, available at www.foam.org/museum/programme/ai-weiwei and Ai Weiwei, Unbroken, exhibition at Gardiner Museum Toronto, available at www.gardinermuseum.on.ca/event/ai-weiwei-unbroken/ and legalsightseeing.org/2019/04/04/legalsightseeing-toronto-ai-weiwei-unbroken/.

${ }^{43}$ Forensic Architecture, 'about', available at forensic-architecture.org/about/agency; also legalsightseeing.org/2019/01/28/ forensic-justice-at-bak-utrecht/.

${ }^{44}$ To download this exhibition see www.icc-cpi.int/display-exhibit. For an analysis see Schwöbel-Patel, supra note 7. On the relation between the ICC and art see also S. Koulen, 'Blind Justice and the Portraits on the Wall', in J. M. Boer and S. Stolk, Backstage Practices of Transnational Law (2018).

${ }^{45}$ D. Litwin, 'International Adjudication from the Visual: Stained Glass Windows, Peace Palace, The Hague', in Hohmann and Joyce, supra note 4.

${ }^{46}$ See, for example, S. Shefik, 'Reimagining Transitional Justice through Participatory Art', (2018) 12 International Journal of Transitional Justice 314; Recently, multiple initiatives have been launched to facilitate and promote the interaction between art and international justice specifically, for example, the Art and International Justice Initiative, available at www.artij.org and Creating Rights, www.creatingrights.com.
} 


\section{Conclusions}

Along these three legal sightseeing stops, we have mostly left out two important questions: Why do institutions welcome tourists? and: Why do tourists visit these sites? The first question is closely related to debates on the legitimacy, accountability and transparency of international institutions, ${ }^{47}$ and fits well within the debate on the 'managerial turn' in international law 'where justice becomes a product, citizens become consumers'. ${ }^{48}$ The second question appeals to social-legal inquiries into the motives of visitors and the way in which international law and justice are experienced, conceptualized and evaluated within society. Studies in tourism and travel have identified an array of motives for going to certain places - people are looking for example for a learning experience, a recreational experience, an emotional experience, perhaps, particularly in the case of memorials, healing and reconciliation. ${ }^{49}$ Engaging in legal sightseeing can, moreover, be motivated by a wish to partake in a process of justice, to support or resist a particular case or court and to be heard and seen by the international community. ${ }^{50}$ While these discussions are important and relevant, we initially want to pause and look at the moment of interaction instead of what comes before or after. By studying the encounter itself rather than its production or reception, we find ourselves in a grey zone between sender and receiver, open to surprises, where anything is still possible.

By emphasizing the element of surprise on the one hand, and recognition on the other, we would like to remain open to different ways of interpreting or approaching these manifestations of legal sightseeing. In some ways, we sympathize with the criticism of dark tourism literature as well as critical legal studies on the commercialization of suffering and its potential moral inappropriateness. However, with introducing the legal sightseeing project, we do not mean to give it a negative connotation. Probably, international lawyers all go legal sightseeing. We take pictures of the Peace Palace when we visit it with our students, we are intrigued when we find a memorial of Judge Pal in Tokyo, ${ }^{51}$ we are honoured to be invited for a Q\&A session after a film screening, ${ }^{52}$ and we are inclined to visit an exhibition about a fictional tribunal in the DRC. ${ }^{53}$

Again, we do not deny that these practices also evoke a certain feeling of discomfort in us. Relating back to the question 'what is international law doing here?', we find ourselves between excitement and astonishment about the touristic potential of international law. In order to articulate this discomfort, we mobilize visual means. We collect photos that show how playfulness and a sense of seriousness go hand-in-hand. To follow Hohmann and Joyce, we like to see playfulness

\footnotetext{
${ }^{47}$ See Hayashi and Bailliet, Bianchi and Peters, Dobson, all supra note 12.

${ }^{48}$ Stolk and Vos, supra note 2. On the marketing of international institutions see C. Schwöbel-Patel, Marketing Global Justice (forthcoming).

${ }^{49}$ On motivations for tourists to visit certain sites see, for example, Y. Poria, R. Butler and D. Airey, 'Links Between Tourists, Heritage, And Reasons For Visiting Heritage Sites', (2004) 43 Journal of Travel Research 19; A. Milosevic 'Can memorials heal the wounds?', (2019) 2 Observing Memories 56.

${ }^{50}$ Little ethnographic research is done on the visitors to international courthouses or other international legal institutions. For ethnographic work into the perception of international justice see, for example, S. Nouwen, Complementarity in the Line of Fire: The Catalysing Effect of the International Criminal Court in Uganda and Sudan (2013); N. Eltringham, 'Spectators To The Spectacle Of Law: The Formation Of A "Validating Public” At The International Criminal Tribunal For Rwanda', (2012) 77 Ethnos 425; K. M. Clarke, Affective Justice: The International Criminal Court and the Pan-Africanist Pushback (forthcoming). There is a growing body of anthropological and ethnographic studies on international lawyers working at these sites or people who participate in the institutional processes; see, for example, Koulen, supra note 44; J. Meierhenrich (ed.), Social Theory of International Law: Thick Descriptions of the International Criminal Court (forthcoming); S. Dezalay, 'Weakness as Routine in the Operations of the Intentional Criminal Court', (2017) 17 International Criminal Law Review 281; R. Niezen and M. Sapignoli, Palaces of Hope: The Anthropology of Global Organizations (2017); S. E. Merry, Human Rights And Gender Violence: Translating International Law Into Local Justice (2009); A. Riles, The Network Inside Out (2001).

${ }^{51}$ M. A. Drumbl, 'Judge Pal with Jefferson Davis in Tokyo', Legal Sightseeing, 15 March 2019, available at legalsightseeing. org/2019/03/15/judge-pal-with-jefferson-davis-in-tokyo/.

${ }^{52}$ legalsightseeing.org/2019/03/25/movies-that-matter-festival/

${ }^{53}$ Stroom, 'Milo Rau: The Congo Tribunal', available at www.stroom.nl/activiteiten/tentoonstelling.php?t_id=4675890.
} 
as a critical tool that can inverse, displace, demystify, and 'loosen the deadening grasp of stale forms, styles, doctrines, and fictions' ${ }^{54}$ We aim to further analyse and theorize the coexistence of playful and serious in the realm of legal sightseeing but also to explicitly show it, with visuals, as a move from studying international law's visuality to visualizing international law as a means of study ${ }^{55}$ We would like to end this editorial with an invitation to visualize legal sightseeing with us. At least, the wide occurrence of legal sightseeing evidences that international law persists, transforms and travels through trivial means and unexpected encounters waiting to be explored by scholars and tourists alike.

\footnotetext{
${ }^{54}$ Hohmann and Joyce, supra note 4 , at 6 .

${ }^{55}$ On making images as research data see Rose, supra note 5, at 307. For recent works that include images as part of research data/dissemination in international law see Hohmann and Joyce supra note 4; R. Parfitt, 'The Anti-Neutral Suit: International Legal Futurists, 1914-2017', (2017) 5 London Review of International Law 87; L. Eslava, 'Istanbul Vignettes: Observing the Everyday Operation of International Law', (2014) 2 London Review of International Law 3. We have experimented with this approach during a walking tour and art workshop during our section (In)Visible International Law at the European International Studies Association (EISA) 13th Pan-European Conference on International Relations (PEC19), 11-14 September 2019, Sofia, Bulgaria. For the results see legalsightseeing.org/2019/09/13/sofia-bulgaria-in-collages-workshopvisualising-international-law/.
}

Cite this article: Stolk S and Vos R (2020). International legal sightseeing. Leiden Journal of International Law 33, 1-11. https://doi.org/10.1017/S0922156519000682 